\title{
PERUBAHAN PARADIGMA MENGAJAR GURU DALAM MENYONGSONG PENYELENGGARAAN PENDIDIKAN DI ERA REVOLUSI INDUSTRI 4.0
}

\author{
Fuaddudin \\ Institut Agama Islam (IAI) Muhammadiyah Bima \\ Email: fuadkarumbu@gmail.com
}

\begin{abstract}
Abstrak
Guru sebagai salah satu aspek tenaga pendidik dalam penyelenggaraan pendidikan Nasional juga perlu melakukan perubahan paradigma dalam melakukan tugas profesionalitasnya sebagai tenaga pendidik. Undang-undnag No. 14 Tahun 2005 tentang Guru dan Dosen menuntut adanya kompetensi profesi Guru untuk terus mengembangkan kualifikasi akademik dan kompetensi sejalan dengan perkembangan ilmu pengetahuan, teknologi dan seni. Perubahan dimensi penyelenggaraan pendidikan harus segera dijawab oleh guru sebagai skema pelaksanaan pembelajaran di sekolah sehingga harapan untuk mencipatakan kecakapan hidup (life skill) atau kecakapan kompetensi (life competency) mampu dicapai oleh seorang guru. Pada fase revolusi industri 4.0, kecakapan hidup harus berlandaskan pada kecakapan penggunaan teknologi digital (use digital teknology).Perubahan paradigma mengajar dengan menggunakan model dan metode belajar berbasis digital menjadikan guru mampu menjawab persoalan tuntutan pemanfaatan perkembangan teknologi digital. Perubahan paradigma mengajar guru harus mampu memanfaatkan kemudahan yang disajikan tersebut. Profesionalitas guru pada era ini harus ditunjukkan dengan keselarasan kompetensi guru dengan tuntutan global. Masa mendatang, perlu adanya indikator yang memuat kemampuan guru dalam menjawab tantangan global sebagai ukuran dalam menseleksi perekrutan guru sebagai sumberdaya pendidik dalam pelaksanaan sistem pendidikan Nasional Indonesia.
\end{abstract}

Kata Kunci: Mengajar, Pendidikan, Revolusi Industri 4.0

\section{PENDAHULUAN}

$\mathrm{P}$

erubahan paradigma kehidupan menjadi hal pokok saat ini. Situasi global yang cenderung dinamis, menuntut kita untuk terus melangkah maju untuk melakukan perubahan. Demikian halnya dengan perubahan paradigma kehidupan. Perubahan paradigma mengatur alurnya untuk senantiasa bergerak beringan dengan dinamika global yang saat ini terus mengalami percepatan. Mengusung peningkata kualitas penyelenggaraan pendiikan, amat perlu memerhatikan alur perubahan ini. 
Peningkatan kualitas pendidikan memerlukan perubahan paradigma dalam berbagai aspek pendukung pendidikan. Undangundang pokok pendidikan yang tertuang dalam UU NO. 20 Tahun 2013 tentang Sistem Pendidikan Nasional telah menetapkan alur pengembangan sistem pendidikan yang dicita-citakan. Peraturan Pemerintah No. 19 Tahun 2005 Tentang standarisasi pendidikan Nasional yang kemudian direvisi melalui PP No. 32 Tahun 2013 telah memuat standar penyelenggaraan pendidikan nasional Indonesia. Melalui standar tersebut, tentu hal itu menjadi kompas pelaksanaan penyelenggaraan pendidikan nasional dengan standar yang telah ditentukan. Namun, dinamika global yang saat ini berlansung cukup kencang menuntut adanya perubahan yang selaras dengan dinamika global.

Era Revolusi Industri yang telah memasuki fase ke empat (revolusi Industri 4.0) telah banyak mewarnai cara pandang, corak produksi dan psikologi sosial yang berbasis teknologi digital. Era revolusi Industri 4.0 melahirkan situasi distruptif teknologi yang sangat kencang. Situasi distruptif ini menuntut adanya perubahan cepat secara beriringan pada paradigma semua aspek kehidupan. Perubahan paradigma ini, perlu juga dilakukan dalam sektor pendidikan. Merujuk pada delapan aspek standar Nasional Penyelenggaraan pendidikan Indonesia yang tertuang dalan PP No. 19 Tahun 2005 tentu menuntut adanya perubahan cepat dalam menyongsong era revolusi Industri 4.0. Jika diselaraskan dengan tuntutan era revolusi industri 4.0 maka delapan aspek satandarisasi pendidikan Nasional Indonesia juga akan mengalami perubahan paradigma. Standar isi dalam penyelenggaraan pendidikan Nasional Indonesia harus memenuhi tuntutan era 4.0 seperti kebutuhan corak produksi industrial, psikologi sosial dan cara pendang masyarakat. Demikian pula standar Proses, standar kompetensi lulusan, standar pendidik dan tenaga kependidikan, standar sarana dan prasarana, standar pengelolaan, standar pembiayaan dan satandar penilaian pendidikan harus memenuhi tuntutan era revolusi industri 4.0. tuntutan perubahan ini, tentunya harus menjadi tantangan yang harus dijawab dengan menampilkan strategi-strategi yang terbuka dan konsisten. 
Guru sebagai salah satu aspek tenaga pendidik dalam penyelenggaraan pendidikan Nasional juga perlu melakukan perubahan paradigma dalam melakukan tugas profesionalitasnya sebagai tenaga pendidik. Undang-undnag No. 14 Tahun 2005 tentang Guru dan Dosen menuntut adanya kompetensi profesi Guru untuk terus mengembangkan kualifikasi akademik dan kompetensi sejalan dengan perkembangan ilmu pengetahuan, teknologi dan seni. Tuntutan profesionalitas ini tentunya harus berselaras dengan perkembangan yang berlaku saat ini. Dinamika perkembangan global yang telah masuk pada fase revolusi industri 4.0 menuntut guru agar sensitif menanggapi tantangan ini sebagai kewajiban dalam mengembangkan kualifiksai akademik dan kompetensinya. Guru dituntut untuk tanggap terhadap perubahan ini, sehingga kualifikasi Guru tidak tertingal jauh oleh tuntutan perkembangan global yang berlangsung sangat cepat.

Tunututan perkembangan global yang telah memasuki fase revolusi 4.0 menuntut adanya perubahan yang cepat pula pada proses penyelenggaraan pendidikan Nasional. Guru sebagai ujung tombak dalam penyelenggaraan pendidikan tentu harus melakukan perubahanperubahan mendasar dalam melaksanakan tugas profesionalitasnya sebagai tenaga pendidik. Salah satu aspek perubahan dalam menjawab tantangan global tersebut adalah dengan melakukan perubahan paradigma mengajar. Perubahan paradigma mengajar harus dilakukan dalam beberapa aspek yaitu: 1) paradigma mengajar harus menjawab tantangan pendidikan di era revolusi industri 4.0,2) paradigma mengajar harus memenuhi tuntutan perubahan model dan metode belajar terbarukan dan 3) perubahan paradigma mengajar harus memenuhi tuntutan perkembangan media belajar yang berbasis teknologi digital.

\section{TINJAUAN TEORITIS}

\section{Paradigma Mengajar Guru}

Mengajar merupakan tugas yang membutuhkan suatu perhatian yang khusus bagi guru, karena dalam mengajar terdapat aspek-aspek psikologis yang harus diketahui guru dalam mengajar, yaitu guru harus mampu untuk (1) Mengarahkan dan membimbing belajar (2) Menimbulkan motivasi pada murid-murid untuk belajara (3) Membantu 
murid-murid dalam mengembangkan sikap yang baik dan dinginkan (4) Meperbaiki tekhnik mengajar (5) Mengenal dan mengusahakan terbentuknya pribadi yang kuat serta berguna dalam rangka usaha untuk memperoleh sukses dalam mengajar $\left({ }^{1}\right.$ L. Crow and Crow, 1998). Dalam mengajar seorang guru harus mempunyai empat kompetensi dasar yaitu kompetensi professional, kompetensi kepribadian, kompetensi sosial, dan kompetensi pedagogik (Sudarwan Danim, 2010).

1. Kompetensi Profesional

Merupakan penguasaan materi pembelajaran secara luas dan mendalam yang harus dikuasai oleh guru mencakup penguasaan materi kurikulum, mata pelajaran di sekolah dan substansi keilmuan yang menaungi materi, serta penguasaan terhadap struktur dan metodologi keilmuan.

2. Kompetensi Kepribadian

Merupakan kemampuan personal yang mencerminkan kepribadian yang mantab, stabil, dewasa, arif, berakhlak mulia dan berwibawa dan dapat menjadi teladan bagi siswa.

3. Kompetensi Sosial

Kemampuan yang harus dimiliki guru untuk berkomunikasi dan bergaul secara efektif dengan siswa, sesame pendidik, tenaga kependidikan, orang tua/wali siswa, dan masyarakat sekitar (Suryanto dan Asep Jihad, 2013).

4. Kompetensi Pedagogik

Menguasai karakteristik peserta didik dari aspek fisik, moral, kultural, emosional dan intelektual, menguasai teori-teori belajar dan prinsip-prinsip pembelajaran yang mendidik. Mengembangkan kurikulum yang terkait dengan mata pelajaran atau bidang pengembangan yang diampu, melakukan tindakan refleksi untuk peningkatan kualitas pembelajaran (Marselus R. Payong, 2011).

Agar melaksanakan tugasnya dengan baik dalam mengajar, maka guru dituntut untuk dalam beberapa hal:

1. Kemampuan merumuskan tujuan pembelajaran

2. Penguasaan prinsip belajar mengajar

3. Penguasaan sumber belajar 
4. Penguasaan pendekatan, metode dan tekhnik belajar mengajar

5. Kemampuan menggunakan sarana belajar dengan baik

6. Kemampuan mendorong siswa untuk belajar secara aktif

7. Kemampuan penguasaan bahan ajar

8. Kemampuan mengelola kelas

9. Mengelola program belajar mengajar

10. Kemampuan menggunakan media (Sardiman AM, 2004)

Untuk merealisasikan hakikat mengajar yang sesungguhnya di sekolah, guru harus memiliki pengetahuan/bidang ilmu yang diajarkan secara luas dan mendalam, itikad baik untuk membagi ilmu pengetahuan yang dimiliki dengan siswa, dan komitmen untuk terus belajar sepanjang hayat. Komitmen guru untuk belajar dalam konteks ini mencakup belajar bidang ilmu yang diajarkan, belajar memaklumi siswanya, serta belajar metode, jika guru merasa yakin bahwa cara atau metode mengajarnya tidak memadai, mak ia harus memperbaikinya melalui berbagai pelatihan, membaca berbagai buku baru pada bidang pembelajaran tersebut, dan mengakses internet untuk mencari berbagai metode pembelajaran baru yang bisa diadopsi. Semua itu dilakukan untuk meningkatkan kemampuan mengajarnya (Suryanto dan Asep Jihad, 2013).

\section{Pendidikan di Era Revolusi 4.0}

Keberhasilan suatu Negara dalam menghadapi revolusi industry 4.0 turut ditentukan oleh kualitas pendidik seperti guru. Guru dituntut menguasai keahlian, kemampuan beradaptasi dengan teknologi baru dan tantangan global. Dalam situasi ini, setiap lembaga pendidikan harus mempersiapkan orientasi dan literasi baru dalam bidang baca, tulis, matematika harus diperkuat dengan mempersiapkan literasi baru yaitu literasi data, teknologi dan sumberdaya manusia. Literasi adalah kemampun untuk membaca, analisa dan menggunakan informasi dari data dalam dunia digitas. Kemudian, literasi teknologi adalah kemampuan untuk memahami system mekanika dan teknologi dalam dunia kerja (Brian Sudlow, 2018).

Pendidikan 4.0 adalah respons terhadap kebutuhan revolusi industri 4.0 dimana manusia dan teknologi diselarasakan untuk 
menciptakan peluang-peluang baru dengan kreatif dan inovatif. Menurut Fisk sebagaimana dikutip oleh Azis Hussin, ada sembilan trend an kecendrungan terkait dengan pendidikan 4.0, yakni sebagai berikut (Anealka Azis Hussin, 2018):

1. Belajar pada waktu dan tempat yang berbeda. Siswa akan memiliki lebih banyak kesempatan untuk belajar pada waktu dan tempat. Elearning memfasilitasi kesempatan untuk pembelajaran jarak jauh dan mandiri.

2. Pembelajaran individual. Siswa akan belajar dengan peralatan belajar yang adaptif dengan kemampuannya. Ini menunjukan bahwa siswa pada level yang lebih tinggi ditantang dengan tugas dan pertanyaan yang lebih sulit ketika setelah melewati derajat kompetensi tertentu

3. Siswa memiliki pilihan dalam menentukan bagaimana mereka belajar. Meskipun setiap mata pelajaran yang diajarkan bertujuan untuk tujuan yang sama, cara menuju tujuan dan dapat bervariasi bagi setiap siswa.

4. Pembelajaran berbasis proyek. Siswa saat ini harus sudah dapat beradaptasi dengan pembelajaran berbasis proyek, demikian juga dalam hal bekerja. Ini menunjukan bahwa mereka harus belajar bagaimana menerapkan keterampilan mereka dalam pendek ke berbagai situasi.

5. Pengalaman lapangan. Kemajuan teknologi memungkinkan pembelajaran domain tertentu secara efektif, sehingga memberi lebih banyak ruang untuk memperoleh keterampilan yang melibatkan pengetahuan siswa dan interaksi tatap muka.

6. Interprestasi Data. Perkembangan teknologi komputer pada akhirnya mengemabil alih tugas-tugas analisis yang dilakukan secara manual dan segera menangani setiap analisis statistic, mendeskripsikan dan menganalisis data serta memprediksi tren masa depan. Oleh karena itu, interprestasi siswa terhadap data ini akan menjadi bagian yang jauh lebih penting dari kurikulum masa depan.

7. Penilaian beragam. Mengukur kemampuan siswa melalui tekhnik penilaian konvensional seperti Tanya jawab akan menjadi tidak relevan lagi atau tidak cukup. Penilaian harus berubah, pengetahuan factual siswa dapat dinilai selama proses pembelajaran, dan 
penerapan pengetahuan dapat diuji saat siswa mengerjekan proyek mereka di lapangan.

8. Keterlibatan siswa. Keterlibatan siswa dalam menentukan materi pembelajaran atau kurikulum menjadi sangat penting. Pendapat siswa dipertimbangkan dalam mendesain dan memperbarui kurikulum.

9. Monitoring. Pendampingan atau pemberian bimbingan kepada peserta didik menjadi sangat penting untuk membangun kemandirian belajar siswa. Pendampingan menjadi dasar bagi keberhasilan siswa, sehingga menuntut guru untuk menjadi fasilitator yang akan membimbing siswa menjadi proses belajar mereka.

Berdasarkan uraian diatas, revolusi industry 4.0 yang ditandai dengan teknologi memiliki implikasi yang signifikan terhadap system pendidikan. Perubahan dan penyesuaian penting yang perlu dilakukan dalam system pendidikan untuk merespons revolusi digital, sehingga output pendidikan dapat bersaing dan berkontribusi secara global.

\section{PEMBAHASAN}

\section{Tantangan Pendidikan di Era Revolusi Industri 4.0}

Penyelengga raan pendidikan mesti menjawab tuntutan perkembangan zaman. Keharusan ini mesti ditetapkan dalam bentuk implementasi pelaksanaan konsep pendidikan yang teleh ditetapkan. Implemenntasi konsep pendidikan tentu tidak selalu ideal dengan harapan yang telah ditetapkan. Walaupun demikian, perlu ada usaha yang serius untuk menjawab tuntutan peradaban tersebut.

Menelisik persoalan tantangan pendidikan pada era revolusi 4.0 harus melihat dimensi-dimensi perubahan yang terjadi. Saat ini setidaknya ada tiga hal besar yang terus mengalami perubahan secara fundamental yaitu: cara pandang, corak produksi dan psikologi sosial yang berbasis teknologi digital. Perubahan-perubahan tatanan global yang harus dijawab antaralain: perubahan cara pandang kehidupan masyarakat lokal ke masyarakat global, perubahan dari kohesi sosial menjadi partisipasi demokrtis, dan perubahan pertumbuhan ekonomi ke perkembangan kemanusiaan. Menjawab tuntutan perubahan dimensi kehidupan global tersebut maka pelaksanaan penyelenggaraan pendidikan mesti berlandaskan pada dua basis landasan: pertama 
pendidikan harus diletakkan pada empat pilar yaitu: belajar mengetahui (learning to know), belajar melakukan (Learning to do), belajar hidup dalam kebersamaan (learning to live togetrher) dan belajar menjadi diri sendiri (lerling to be); kedua belajar seumur hidup (long live learning) (Mulayasa, 2013: 2). Perubahan dimensi penyelenggaraan pendidikan tersebut harus beroreantasi pada membekali peserta didik dengna kecakapan hidup (life skill atau life competency) yang sesuai dengan lingkungan kehidupan dan kebutuhan peserta didik.

Perubahan dimensi penyelenggaraan pendidikan tersebut harus segera dijawab oleh guru sebagai skema pelaksanaan pembelajaran di sekolah sehingga harapan untuk mencipatakan kecakapan hidup (life skill) atau kecakapan kompetensi (life competency) mampu dicapai oleh seorang guru. Pada fase revolusi industri 4.0, kecakapan hidup harus berlandaskan pada kecakapan penggunaan teknologi digital (use digital teknology). Distrupsi perkembangan teknologi digital yang sangat cepat pada era revolusi indistri 4.0 membuka cara pandang masyarakat loka ke masyarakat global tanpa sekat. Keterbukaan informasi yang cukup fleksibel membuat cara pandang masyarakat berlangsung sangat luas sehingga membutuhkan kecakapan digital yang baik sehingga tidak tertinggal dari tuntutan perkembangan global yang berlangsung cepat. Pergeseran kohesi sosial dalam partisispasi demokratis menuntut masyarakat agar memiliki kecakapan dan kearifan dalam menggunakan teknologi digital yang bijak. Selain itu, pola produksi ekonomi yang merujuk pada kebutuhan hidup manusia menuntut adanya kecakapan penggunaan teknologi digital untuk menopang kehidupan kemanusiaan. Maka, pendidikan sebagai laboratorium kehidupan sosial kemasyarakatan harus mampu menjadi miniatur bagi keberlangsungan kehidupan manusia. Perubahan paradma mengajar guru harus menjawab tuntutan kehidupan yang berkembang tersebut. Guru sebagai ujung tombang pelaksanaan pendidikan di sekolah membutuhkan strategi mengajar yang tepat dalam menjawab perubahan-perubahan tersebut. Pengajaran di sekolah tidak boleh terjadi kesenjangan dengan kondisi objektif secara kekinian yang berkembang di masyarakat. Guru harus 
mampu menampilkan strategi mengajar yang mampu menjawab tantangan penyelenggaraan pendidikan di era revolusi industri 4.0.

\section{Perubahan Model dan Metode Mengajar Terbarukan}

Menghadapi era revolusi industri 4.0 perlu adanya perubahan mendasar pada paradigma penggunaan model dan metode pembelajaran yang digunakan dalam pengajaran. Guru memiliki keharusan untuk melakukan inovasi yang komprehensi dalam menerapkan model pembelajaran. Langkah inovatif yang mesti dilakukan adalah dengan memanfaatkan teknologi digital sebagai dasar dalam merancang model pembelajaran. Perkembangan teknologi digital menawarkan ruang inovasi yang luas dalam merancang model pembelajaran berbasis digital seperti blended learning, hybird learning, computer based learning, dan web based learning (Ubaidah Published at : 23 November 2018). Untuk mengembangkan model dan metode belajar tersebut guru harus mampu merubah paradigma mengajar yang konvensional menjadi paradigma mengajar yang terbarukan. Setidaknya ada beberapa hal yang harus dipenuhi oleh guru untuk merancang model dan metode pembelajaran terbarukan di era revolusi industri 4.0: Pertama, keterampilan berpikir kritis dan pemecahan masalah (critical thinking and problem solving skill), kedua, keterampilan komunikasi dan kolaboratif (communication and collaborative skill), Ketiga, keterampilan berpikir kreatif dan inovasi (creativity and innovative skill), Keempat, literasi teknologi informasi dan komunikasi (information and communication technology literacy), Kelima, contextual learning skill, Keenam, literasi informasi dan media (information and media literacy) (Darmawan Jon, Selasa, 27 November 2018 08:16). Melalui enam hal ini, guru akan mampu melakukan perubahan paradigma mengajar sesuai dengan tuntutan revolusi industri 4.0 .

Perubahan paradigma mengajar dengan menggunakan model dan metode belajar berbasis digital menjadikan guru mampu menjawab persoalan tuntutan pemanfaatan perkembangan teknologi digital. Dengan menggunakan model dan metode terbarukan tersebut maka, guru akan mampu menjawab persolan-persoalan pembelajaran yang terjadi selama penggunaan metode dan model pembelajaran konvensional. Selama ini, 
guru sering dihadapkan pada persoalan pembelajaran yang monoton, pembelajaran tersentral kepada guru, minimnya kreatifitas pembelajaran, rendahnya motivasi belajar dan lain-lain. Dengan pemanfaatan teknologi digital, ruang pembelajaran yang diterapkan guru tidak lagi sempit pada ruang dan waktu yang terbatas. Guru akan mampu meningkatkan kreatifitasnya melalui pembelajaran yang berbasis teknologi digital. Saat ini, perubahan dimensi kehidupan yang ditawarkan oleh perkembangan teknologi digital pada era revolusi industri 4.0 menuntut guru harus menselaraskan strategi mengajarnya dengan tuntutan perubahan tersebut. Kecapan hidup yang ingin dicapai oleh peserta didik dapat tercapai dengan menggunakan model dan metode pembelajaran yang berbasis teknologi digital.

\section{Media Belajar Yang Berbasis Teknologi Digital}

Menselaraskan antara tantangan pendidikan, penggunaan model dan metode pembelajaran terbarukan dan penggunaan media belajar dalam pembelajaran di era revolusi industri 4.0 memerlukan adanya perubahan paradigma mengajar dengan menggunakan media yang berbasis teknologi digital. Pemanfaatan teknologi digital sebagai media belajar sesungguhnya mempermudah guru dalam menyiapkan media belajar. Penggunaan tenologi digital untuk media belajar merupakan penerapan konsep teknologi pembelajaran. Pemanfaatan teknologi digital untuk media pembelajaran merupakan penerapan digital learning ini menjadikan pelajar lebih mandiri dan mendalami materi bahan ajar, karena pelajar dapat belajar kapan saja dan di mana saja. Evaluasi pembelajaran dilakukan oleh guru secara otomatis melalui proses digital, sehingga tidak perlu pengoreksian secara manual melalui kertas. Hasil evaluasi yang diperoleh pun akan lebih cepat, akurat, dan objektif. Digital learning juga dapat menyatukan semua kegiatan belajar mengajar yang biasa dilakukan secara konvensional ke dalam bentuk digital (Habibie, Posted by nida on Nov 25, 2010 in saintek).

Arsyad dalam Andika L. R. (2016: 7) menyatakan macammacam media pembelajaran meliputi media berbasis manusia (guru, tutor, main peran, kegiatan kelompok, dll), media berbasis cetakan (buku, Buku kerja/latihan), media berbasis visual (buku, chart, grafik, 
peta gambar, dll), media berbasis audio visual (film, televisi), dan media berbasis komputer (pengajaran dengan bantuan komputer dan video interaktif). Jenis media yang disampaikan di atas, mampu disentralkan dalam satu fram melalui pemanfaatan teknologi digital seperti unit anroid dan unit komputer. Pemanfaatan multi media dalam merancang media pembelajaran menisbikan keterbatasan ruang dan waktu yang dihadapi dengan menggunakan media konvensional.

Media pembelajaran yang dirancang oleh guru pada pembelajaran di era revolusi 4.0 mesti diselaraskan dengan tuntutan kemudahan yang disajikan oleh perkembangan teknologi digital tersebut. Perubahan paradigma mengajar guru harus mampu memanfaatkan kemudahan yang disajikan tersebut. Guru pada era revolusi industri 4.0 harus menselaraskan kompetensinya untuk mampu memanfaatkan potensi ini. Ketika guru tidak mampu menjawab tuntutan ini maka, guru akan mengalami ketertinggalan dalam memenuhi kebutuhan kecakapan hidup dan kompetesi yang dibutuhkan siswa.

Perubahan paradigma mengajar yang disampaikan di atas, merupakan tantangan yang mesti dijawab oleh guru dalam menyongsong penyelenggaraan pendidikan di era revolusi industri 4.0. kesediaan guru dalam menjawab tantangan ini, tentu akan menjadi faktor utama dalam meningkatkan kualitas penyelenggaraan pendidikan yang berselaras dengan tuntutan perkembangan global yang telah memasuki fase era revolusi industri 4.0. Ketidak sanggupan guru dalam menjawab tuntutan global yang saat ini berlangsung akan mengkikis kualitas penyelenggaraan pendidikan Nasional indonesia dan memperdalam jurang ketertinggalan sektor pendidikan Nasional dalam mengejar perubahan dimensi kehidupan yang berlangsung sangat cepat. Saat ini amat dibutuhkan guru yang responsif dalam menghadapi tantangan perkembangan global. Responsif guru dalam menjawab tantangan menjadi indikator utama dalam menyongsong penyelenggaraan pendidikan di era revolusi industri 4.0. Profesionalitas guru pada era ini harus ditunjukkan dengan keselarasan kompetensi guru dengan tuntutan global. Masa mendatang, perlu adanya indikator yang memuat kemampuan guru dalam menjawab tantangan global senagai ukuran 
dalam menseleksi perekrutan guru sebagai sumberdaya pendidik dalam pelaksanaan sistem pendidikan Nasional Indonesia. Saat ini, dalam menjawab tuntutan perkembangan global mesti adanya pembinaan peningkatan kapasitas terhdap sumberdaya tenaga pendidik. Pembinaan peningkatan kapasitas tenaga pendidik akan menjadi pintu awal dalam merubah paradigma mengajar guru dalam menyongsong penyelenggaraan pendidikan Nasional Indonesia.

\section{SIMPULAN}

Perubahan dimensi penyelenggaraan pendidikan harus segera dijawab oleh guru sebagai skema pelaksanaan pembelajaran di sekolah sehingga harapan untuk mencipatakan kecakapan hidup (life skill) atau kecakapan kompetensi (life competency) mampu dicapai oleh seorang guru. Pada fase revolusi industri 4.0, kecakapan hidup harus berlandaskan pada kecakapan penggunaan teknologi digital (use digital teknology).

Perubahan paradigma mengajar dengan menggunakan model dan metode belajar berbasis digital menjadikan guru mampu menjawab persoalan tuntutan pemanfaatan perkembangan teknologi digital. Dengan menggunakan model dan metode terbarukan tersebut maka, guru akan mampu menjawab persolan-persoalan pembelajaran yang terjadi selama penggunaan metode dan model pembelajaran konvensional. Saat ini, perubahan dimensi kehidupan yang ditawarkan oleh perkembangan teknologi digital pada era revolusi industri 4.0 menuntut guru harus menselaraskan strategi mengajarnya dengan tuntutan perubahan tersebut. Kecapan hidup yang ingin dicapai oleh peserta didik dapat tercapai dengan menggunakan model dan metode pembelajaran yang berbasis teknologi digital.

Media pembelajaran yang dirancang oleh guru pada pembelajaran di era revolusi 4.0 mesti diselaraskan dengan tuntutan kemudahan yang disajikan oleh perkembangan teknologi digital tersebut. Perubahan paradigma mengajar guru harus mampu memanfaatkan kemudahan yang disajikan tersebut. Guru pada era revolusi industri 4.0 harus menselaraskan kompetensinya untuk mampu memanfaatkan potensi ini. Ketika guru tidak mampu menjawab tuntutan ini maka, guru 
akan mengalami ketertinggalan dalam memenuhi kebutuhan kecakapan hidup dan kompetesi yang dibutuhkan siswa.

Profesionalitas guru pada era ini harus ditunjukkan dengan keselarasan kompetensi guru dengan tuntutan global. Masa mendatang, perlu adanya indikator yang memuat kemampuan guru dalam menjawab tantangan global senagai ukuran dalam menseleksi perekrutan guru sebagai sumberdaya pendidik dalam pelaksanaan sistem pendidikan Nasional Indonesia. Saat ini, dalam menjawab tuntutan perkembangan global mesti adanya pembinaan peningkatan kapasitas terhdap sumberdaya tenaga pendidik. Pembinaan peningkatan kapasitas tenaga pendidik akan menjadi pintu awal dalam merubah paradigma mengajar guru dalam menyongsong penyelenggaraan pendidikan Nasional Indonesia.

\section{DAFTAR PUSTAKA}

Andika L. R. (2016) Pengembangan Media Pembelajaran Berbasis Digital Game Kompetensi Dasar Identifikasi dan Analisis Gangguan Sistem Startel Konvensional (Skripsi). Jurusan Teknik Mesin Universitas Semarang.

Anealka Azis Hussin. 2018 "Education 4.0 Made Simple Ideas For Teaching". International Journal of Education and Literacy Studies.

Brian Sudlow. 2018. "Review of Joseph E. Aoun. Robot Proof: Higher Education in the Age of Artificial Intelligence, "Postdigital Science and Education.

Marselus R. Payong. 2011. Sertifikasi Profesi Guru, Jakarta, Indeks.

Muhali. (2018). Arah Pengembangan Pendidikan Masa Kini menurut Perspektif Revolusi Industri 4.0. Dosen Program Studi Pendidikan Kimia FPMIPA IKIP Mataram muhali@ikipmataram.ac.id

Mulyasa. (2013). Pengembangan dan Implementasi Kurikulum 2013 (Perubahan dan Pengembangan Kurikulum 2013 Merupakan Persoalan Penting dan Genting). Bandung: PT Remaja Rosdakarya.

https://aceh.tribunnews.com/2018/11/27/menjadi-guru-era-pendidikan40? page $=2$

https://pgsd.binus.ac.id/2018/11/23/model-pengembangan-pembelajaranonline-web-based-learning-environment/

http://komunikasi.um.ac.id/2010/11/digital-learning-mediapembelajaranmasa-kini/

L. Crow and Crow. 1998. Psikologi Pendidikan, Yogyakarta, Nur Cahaya.

Sardiman AM. 2004. Interaksi dan Motivasi Mengajar, Jakarta, Raja Grafindo Persada. 
Sudarwan Danim. 2010. Profesionalisasi dan Etika Profesi Guru, Bandung, Alfabeta.

Suyanto dan Asep Jihad. 2013. Menjadi Guru Profesional: Strategi Meningkatkan Kualitas Guru di Era Global, Jakarta, Erlangga. 